DOI: https://doi.org/10.24127/ajpm.v10i4.4221

\title{
NEWMAN ERROR ANALYSIS (NEA): DETECTION OF STUDENT LEARNING BARRIERS IN PPKM IN MATHEMATICS SUBJECTS
}

\author{
Sutama $^{1^{*}}$, Yuni Putri Indriyani ${ }^{2}$ \\ ${ }^{1 *, 2}$ Universitas Muhammadiyah Surakarta, Surakarta, Indonesia \\ ${ }^{*}$ Corresponding author. Jl. A. Yani, Mendungan, Pabelan, Kec. Kartasura, Kabupaten Sukoharjo, Jawa Tengah \\ 57169, Indonesia. \\ E-mail: $\quad$ sutama@ums.ac.id $^{\left.{ }^{*}\right)}$ \\ yuniputrifkipums@gmail.com ${ }^{2)}$
}

Received 14 September 2021; Received in revised form 02 December 2021; Accepted 29 December 2021

\begin{abstract}
The research aims to analyze students' mistakes in solving straight-line equations and to find the learning barriers experienced during distance learning conducted in the 8th grade of a superior private junior high school in Surakarta City. The research uses qualitative descriptive design with assistive instruments in the form of three straight-line equations material test questions and interview guidelines. Triangulation used is a triangulation method and analysis data is done with the stages of data collection, data reduction, data categorization, presentation and withdrawal of conclusions. Referring to the Newman Error Analysis theory, it is identified that all five types of errors are made by students in solving straight-line equations. The five types of errors are reading errors, comprehension errors, transformation errors, process skill errors, and encoding errors. Student errors that appear to indicate obstacles in learning. The rights that arise ontogenic obstacle, minimal learning supervision, and the availability of fewer learning resources. The results of this study can be used as a basis for developing a learning medium that can be used and supporting online teaching.
\end{abstract}

Keyword: Learning barriers; Newman; Pandemic; PPKM.

\begin{abstract}
Abstrak
Penelitian bertujuan untuk menganalisis kesalahan siswa dalam menyelesaikan soal persamaan garis lurus dan untuk menemukan hambatan belajar yang dialami selama pembelajaran jarak jauh dilakukan pada siswa kelas 8 SMP swasta unggulan di Kota Surakarta. Penelitian menggunakan desain deskriptif kualitatif dengan instrumen bantu berupa tiga soal tes materi persamaan garis lurus dan pedoman wawancara. Triangulasi yang digunakan yaitu triangulasi metode dan analisis data dilakukan dengan tahapan pengumpulan data, reduksi data, pengkategoriang data, penyajian dan penarikan kesimpulan. Mengacu pada teori Newman Error Analysis (NEA), teridentifikasi bahwa kelima jenis kesalahan dilakukan oleh siswa dalam menyelesaikan soal persamaan garis lurus. Kelima jenis kesalahan tersebut yaitu reading errors, comprehension errors, transformation errors, process skill errors, and encoding errors. Kesalahan siswa yang muncul menunjukkan adanya hambatan dalam belajar. Hambatan yang muncul yaitu hambatan ontogenik, pengawasan atau kontrol belajar yang minim, dan ketersediaan sumber belajar yang kurang. Hasil penelitian ini dapat dijadikan sebagai dasar untuk mengembangkan sebuah media pembelajaran yang dapat digunakan dan pendukung pembelajaran online.
\end{abstract}

Kata kunci: Hambatan belajar; Newman; Pandemi; PPKM.

This is an open access article under the Creative Commons Attribution 4.0 International License

\section{INTRODUCTION}

The enactment of Community Health Restrictions (PPKM) is the
Indonesian government's policy to reduce people's mobility in the second wave of covid-19 attacks. Previously, the Minister of Education, Culture, 
Research and Technology had planned to carry out face-to-face learning in June 2020 with limited capacity. However, since the emergence of delta variants in Indonesia that caused the number of positively confirmed communities to significantly increase the face-to-face learning plan was eliminated.

Distance learning has been carried out over three semesters since March 2020 (Hendriyanto et al., 2021a). Ideally, distance learning can be implemented well and effectively. But on the contrary, some research reveals that learning in the third semester since the beginning of the pandemic has not been effective (Hendriyanto et al., 2021b). Whatever the reason and how it results, distance learning should be done as effort to prevent the transmission of the covid-19 virus. The principle of education policy during the Covid-19 pandemic prioritizes the health and safety of learners, educators, education personnel, families, and society in general in order to fulfill educational services during the pandemic (Hill et al., 2020).

The current learning paradigm has changed from face-to-face learning to online learning (Fitriana et al., 2021). Currently, online learning is still not effective, but students and teachers be more independent in doing their activities and maximize the utilization of technology and information (Wijaya et al., 2020). Previously, not all students and teachers had IT-based work habits, but this condition allowed them to be more accustomed and skilled at completing work with IT. This positive impact must still exist when face-toface learning can be implemented later. So combining online and face-to-face learning will be a trend in the future.
To prepare for it all, an analysis of the obstacles experienced by students is needed. Student learning barriers will certainly change along with environmental conditions and learning strategies used. This research aims to analyze and describe student learning barriers in mathematics subjects while PPKM takes place. This needs to be done as an early detection effort against the problems experienced by students, so that appropriate action can be taken immediately.

Student learning barriers can be detected through analysis of student errors in solving math problems (Ferdianto \& Hartinah, 2020). When students make repeated mistakes in solving the same problem, of course, they experience learning barriers. Student class analysis can be identified using Newman Error Analysis (NEA) theory.

Newman describes that there are five types of mistakes that students make in solving math problems, namely reading errors, comprehension errors, transformation errors, process skill errors, encoding errors (Siskawati et al., 2021). Through the Newman Error Analysis (NEA), will be known the barriers to learning students are on which aspect.

Errors in solving mathematical problems can be used to detect difficulty learning mathematics so that they can find alternative solutions to solve mathematical problems (Son et al., 2020). Students' difficulties in learning will result in low student learning achievement (Wakefield \&Frawley, 2020).

The low achievement of learning mathematics students are allegedly caused by difficulty understanding mathematics (Hamukwaya \&Haser, 2021). This is not surprising because so 
far mathematics been learning has still conventional and monotonous. Teachers dominate more in the learning process (Ahmadi, 2021). Teachers are more active in preaching compared to students (Sukardi et al., 2021). As a result, the feeling of boredom to learn mathematics at any time can appear in students. Many facts show that at the time of learning, most students are less enthusiastic about accepting it, students are more passive, reluctant, afraid or embarrassed to express their opinions.

\section{RESEARCH METHOD}

This research is included in a type of qualitative descriptive research that aims to describe mistakes made by students in solving mathematical problems on the subject of straight-line equations. The theory of error is Newman Error Analysis (NEA) with assistive instruments in the form of three valid and reliable problems and interview guidelines. Through the test instrument, researchers as a key instrument collect data by analyzing the answer sheet. Next, the researcher conducted an interview by asking the necessary questions in effort to dig deeper into the data.

The research subject are students of class VIII of a superior private junior high school in Surakarta City. It takes ten subjects taken on snowball sampling to get the overall data. Triangulation methods are selected as a step to determine the validity of the data. There are two ways to triangulate the methods in this study: first, comparing the data obtained from one subject to the answer to each problem and second, comparing the data obtained from each subject. Data analysis is carried out in the stages of data collection, data reduction, data categorization, presentation and withdrawal of conclusions.

\section{RESULT AND DISCUSSIONS}

The Newman procedure is a method of analyzing errors in the description. Newman publishes data based on a system he developed to analyze errors made on written tasks. Newman classifies the types of student errors in solving problems into five categories: reading errors, comprehension errors, transformation errors, process skill errors, encoding errors.

The addition of the subject is done based on the type of error that can be described. Here are the types of mistakes made by selected subjects. It's summaries completely described in Table 1.

Table 1. Summary of the types of errors found.

\begin{tabular}{lccccc}
\hline \multirow{2}{*}{ Subject } & \multicolumn{5}{c}{ The type of error } \\
\cline { 2 - 6 } & I & II & III & IV & V \\
\hline S1 & $\sqrt{ }$ & - & - & - & - \\
S2 & - & $\sqrt{ }$ & - & - & - \\
S3 & $\sqrt{ }$ & - & - & - & - \\
S4 & - & - & - & $\sqrt{ }$ & - \\
S5 & - & - & - & $\sqrt{ }$ & - \\
S6 & - & - & $\sqrt{ }$ & - & - \\
S7 & - & - & - & - & $\sqrt{ }$ \\
S8 & - & $\sqrt{ }$ & - & - & - \\
S9 & - & - & $\sqrt{ }$ & - & - \\
S10 & - & - & - & - & $\sqrt{ }$ \\
\hline Description: & \multicolumn{5}{c}{} \\
S1 - S10 & : Subject 1 to 10 \\
I & \multicolumn{5}{c}{ Reading Errors } \\
II & : Comprehension Errors \\
III & Transformation Errors \\
IV & : Process Skill Errors \\
V & \multicolumn{5}{c}{ Encoding Errors }
\end{tabular}

The next, it will show each type of error that occurs. Exposure is limited to research conclusion data, so not all findings will be featured in this article. This research is the first to conduct a larger study on effective learning models used. 


\section{The Description of Reading Errors}

Errors will be classified as reading errors if students are unable to read a keyword or symbol written in the problem, thus preventing it from next processing it to proper troubleshooting. In the first problem the keyword is "gradient", in the second problem the two keywords are "point coordinates" and "cut points", while in the third problem the keywords are "line equations" and "parallel lines".

Reading errors occur in the second problem that is by not understanding the keyword "point coordinates". On this answer sheet, is identified from the absence of wellwritten conclusions. This result is reinforced by one of the subjects $(\mathrm{S} 1)$ during the interview.

\section{$\mathrm{P}$ : How do you find the coordinates of a point? \\ $\mathrm{S} 1$ : Looking for value $x$ and $y$ \\ $\mathrm{P} \quad$ : Then how's the writing? \\ $\mathrm{S} 1$ : Like this (pointing to the answer) $x$ is the same and $y$}

From the results of the interview with $\mathrm{S} 1$ above, it is known that $\mathrm{S} 1$ does not know how to write the coordinates of a point. For cases of "gradients" identified to students who did not answer the first question. During the interview, S3 explained "I don't know what a gradient is, so I'm not working on the first problem".

From the description above, the cause of students experienced reading errors that students do not understand the meaning of words in the problem. Words that are not understood are gradients and point coordinates. Gradient is a value that indicates the slope/incline of a straight line. Coordinates are numbers used to indicate the location of a point in a line, surface or space.

Reading errors is occur if the study subject does not read the words or symbols contained in the problem. In the first step of solving a math problem using the Newman procedure, reading. It is in accordance with research conducted by Isnani et al., (2020) that misreading occurs when written words or symbols fail to be recognized by the subject causing it to fail to solve the problem based on proper settlement measures.

Trapsywi et al., (2021) reveal that common mistakes students make are a lack of understanding of symbols, place values, calculations, incorrect use of processes and illegible writing. In this case student's obstacle cannot identify the information of the questions properly.

\section{The Description of Comprehension Errors}

In this study, student errors were classified as comprehension errors if students did not write down question information on the answer sheet and were unable to explain what was known and asked. Figure 1 shows the S2 answers.

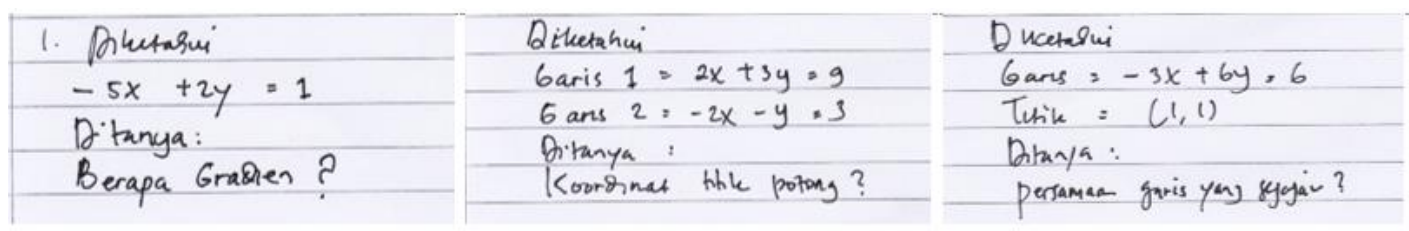

Figure 1. Answer of S2 in Writing Information 
DOI: https://doi.org/10.24127/ajpm.v10i4.4221

S2 is able to write well what is known and asked on the answer sheet. However, during the interview S2 was unable to explain what he wrote. In the first question S2 writes "known: line equation $=-5 x+2 y=1$ and asked: gradient?" From then the second and third question S2 also writes the same thing exactly as seen in Figure 1.

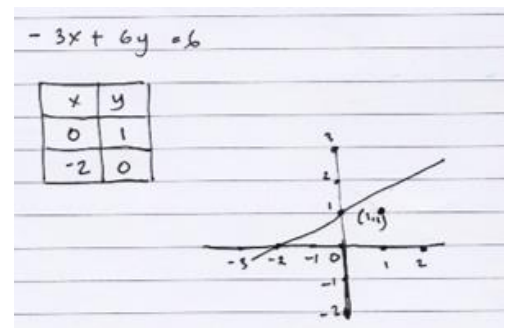

Figure 2. S2 Answer about parallel line

In Figure 2 S2 simply writes a "parallel line" in the questioned problem section without explaining that the line sought must go through the point $(1,1)$ This indicates that S2 ignores information regarding the coordinates of the point. Here is an interview with S2 relating to the answer he wrote.

$\mathrm{P} \quad$ : What information is there in the third question?

$\mathrm{S} 2$ : There is an equation of lines that go through a point $(1,1)$ and are asked to look for parallel lines.

$\mathrm{P}$ : The one through that point $(1,1)$ is a known line or a line to be searched for?

S2 : Known lines

$\mathrm{P}$ : Try now a line drawing that has equation $-3 x+6 y=6$

S2 : S4 draw (look for Figure 2) Here

$\mathrm{P} \quad$ : Where is point $(1,1)$ ?

$\mathrm{S} 2$ : Here (showing coordinate $(1,1)$ on the figure)

$\mathrm{P} \quad$ : Does the line pass the point $(1,1)$ or not?

$$
\begin{aligned}
\mathrm{S} 2: & \text { No } \\
\mathrm{P}: \text { : } & \text { Then how? } \\
\mathrm{S} 2: \text { It means the line which looked } & \text { for through this point } \\
& \text { (showing coordinate }(1,1) \\
& \text { which pointed before) }
\end{aligned}
$$

The cause of this error is that students with the ability are not analyzing more details related to the information they understand.

The case in the second problem is done by S8 who only wrotw the known information without writing the information asked (Figure 3).

$$
\begin{aligned}
& \text { 2. Persamaan Garis } \\
& \text { (i) }-2 x+3 y=9 \\
& \text { (ii) }-2 x-y=-3
\end{aligned}
$$

Figure 3. Answers of S8 in identifying information about the second problem

Then on the third question S8 only writes the equation of the line and the position of the known point (Figure 4). However, there are indications that S8 understands if the point $(1,1)$ is the point through which the line is crossed.

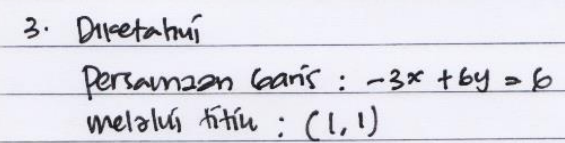

Figure 4. Answer of S8 in identifying information about the third problem

The case in the S8 shows that the model of errors made is the same between the second and third problems, namely not writing information that is known in a long way.

$\mathrm{P}$ : What is known about the second question?

S8 : Line equation

$\mathrm{P} \quad$ : How many the line equations?

$\mathrm{S} 8$ : One

$\mathrm{P}$ : This (pointing other line equation) 
DOI: https://doi.org/10.24127/ajpm.v10i4.4221

S8 : It is the line that cuts

$\mathrm{P} \quad$ : So, it is not the line equation?

S8 : No

$\mathrm{P} \quad$ : What is asked?

S8 : Cut point

$\mathrm{P} \quad$ : From the $3^{\text {rd }}$ question, what is asked and known?

S8 : The asked question is line equation, the thing which known is parallel line

$\mathrm{P} \quad$ : Which line is parallel?

S8 : This (pointing on the line equation)

$\mathrm{P} \quad$ : Where do parallel?

S8 : Everywhere as long as its parallel

$\mathrm{P} \quad$ : What is this? (pointing on coordinate point $(1,1)$ )

S8 : Point equation

$\mathrm{P} \quad$ : What kind of point?

S8 : It just a point

From the explanation of S8, it seems clear that he does not understand the cause of his incomprehension in the material of straight-line equations. According to research, conducted by Hanifah et al., (2020) students make misrepresentation by not writing down information and questions. This happens because students do not understand about the information contained in the problem, and students also do not understand the questions contained in the problem, so the information written by the student is not complete. Looking for the field data, the observation shows that student's has book reference, but they still do not understand as well. In this case, it could be caused lack of learning readiness or defined as ontogenic obstacle). Students tend to be careless in doing questions like this. This is happens when students determine the question one to three. In another case, teachers still can not suspect directly as well.

\section{The Description of Transformation Errors}

The stage where students are able to understand what the problem wants but unable to identify the operations and procedures needed to solve the problem. In other words, transformation errors are errors that occur when students have correctly understood the question but fail to choose the right mathematical operation to solve the problem.

In the sixth (S6) subject, transformation error occurs in the first and third problems. This error is indicated by not writing a formula to find the gradient value so that $y=$ $m x+c$ S6 does not complete the work. Look at Figure 5 for the explanation.

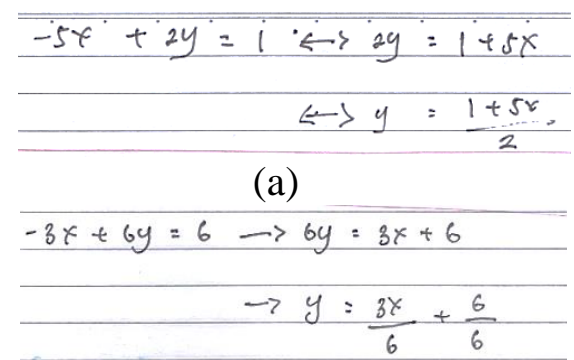

(b)
Figure 5. S6 Does not write the formula. $y=m x+c$ (a) the first question, (b) the third question

In Figure 5 appears that S6 unable to continue what it has to do both on the first and third questions. When interviewed S6 explains that S6 does not understand what the formula is looking for gradients.

$\mathrm{P} \quad$ : How do you find the gradient of the line?

S6 : I do not know

$\mathrm{P} \quad$ : This (point S8's answer) does it done or not?

S6 : It does not yet

$\mathrm{P}$ : Why do you not resolve?

S6 : I do not know the gradient value 
DOI: https://doi.org/10.24127/ajpm.v10i4.4221

Through this observation, it shows that S6 does not understand the material as well. Teachers could not give more explanation, and clarification because distance learning barrier.

Another mistake was made by the S9 while working on the third problem. S9 is incorrect in stating the gradient value statement on a parallel line. S9 writes as $m_{1} \times m_{2}=1$ in Figure 6 .

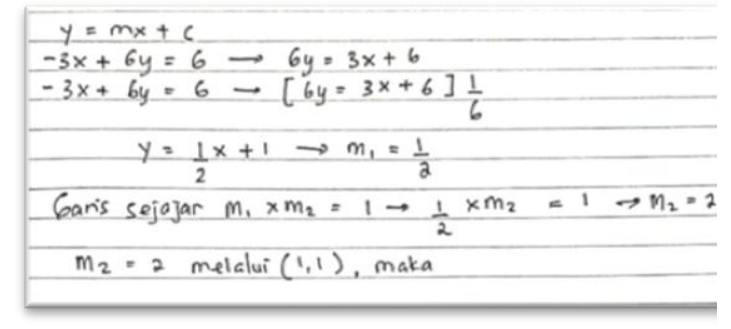

Figure 6. Answer of S9 in finding gradient values in the third problem

In Figure 6, this is used to look for gradient $y=m x+c$ values of known lines. After obtaining the gradient value on the first line S9, writes a statement regarding the parallel line. The true statement is, $m_{1}=m_{2}$ but not what $\mathrm{S} 9$ says.

$\mathrm{P}$ : How does the gradient of parallel line?

S9 : $m_{1} \times m_{2}=1$

$\mathrm{P}$ : How about the perpendicular line?

S9: $m_{1} \times m_{2}=-1$, wait a minute, it means the gradient of parallel line is $m_{1}=m_{2}$

$\mathrm{P} \quad$ : What thing is right?

S9 : Yes, I made a mistake while I am answering the equation. The line is parallel and perpendicular that one of them is multiplied. Now I remembered.
Based on interviews with S9, it is known that that causes $S 9$ to do the error transformation because of $\mathrm{S} 9$ Forgetting about the material when working on the problem.

This transformation error is in accordance with the opinion of Anugrah \&Kusmayadi (2019) which states that mistakes occur at the transformation level because students understand what the question is, but cannot succeed in developing appropriate operations to solve problems.

\section{The Description of Process Skill Errors}

The stage at which the student has been able to identify the appropriate operation or procedure, but does not know the procedures needed to complete the operation accurately. In other words, an error is called process skill errors if the student is able to choose the operation needed to solve the problem, but he is unable to perform the procedure correctly.

Computational error occurs in the third problem when $\frac{1}{2}(x-1)$ multiplying. S4 writes the results of the multiplication that $\frac{1}{2} x-1$ should be like $\frac{1}{2} x-\frac{1}{2}$ (Figure 7 ).

$$
y-1=\frac{1}{2} x
$$

Figure 7. Answers of S4 wrong in doing computing on the third problem

In Figure 7 the error occurs in the 4th row. When interviewed S4 said that "it should be the $\frac{1}{2}$ result". While in students with low ability this error occurs a second problem (Figure 8). 


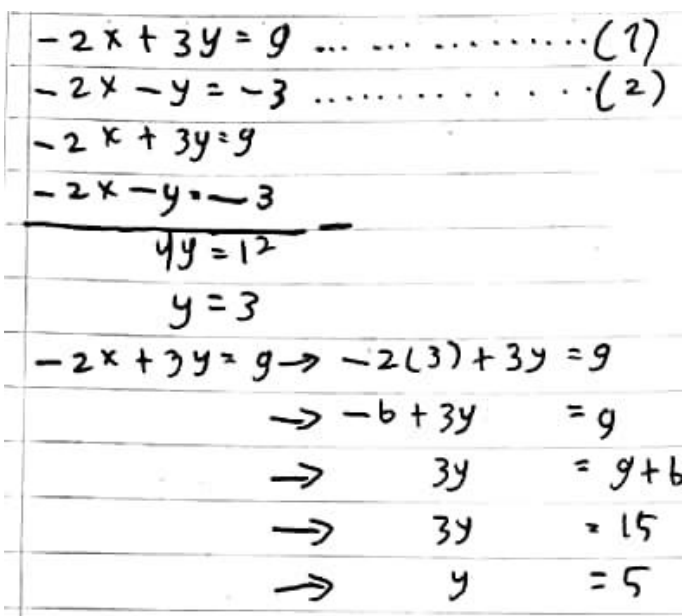

Figure 8. Answers of S5 wrong substitution

Answer of S5 in the second question above occurs when subtitling values $y$, on which can be seen in $x$ the 7 th row in which there should be the value 3 substubsted to but $y$ S5 instead of replacing it on $x$. "Oh yes, I was wrong," S10 said during the interview. From the results of S4 and S5, it is known that this error occurred due to the inaccuracy of students.

This is in line with murtiyasa \& wulandari (2020) that the error of process skills is that the student is able to identify the appropriate operation, or series of operations, but does not know the steps needed to carry out this operation perfectly.

\section{The Description of Encoding Errors}

The stage at which students have found a solution to the problem, but mis-determining the final answer or not presenting the right answer. In other words, a mistake can still occur even if the student has finished solving a math problem, namely, that the student misrepresented what he meant

In S7 found an error in the second problem is to write the coordinates of the $(3,0)$ supposed cut point $(0,3)$ (Figure 9a) and in S10 this error is found in the second problem that is wrong in writing the operation (Figure 9b). The written operation should be (minus) but written + (plus). Encoding errors are mistakes made by students because of the lack of thoroughness of students in writing. At this stage the student has been able to solve the problem desired by the problem, but there is slight lack of student accuracy that causes a change in the meaning of the answer he wrote.

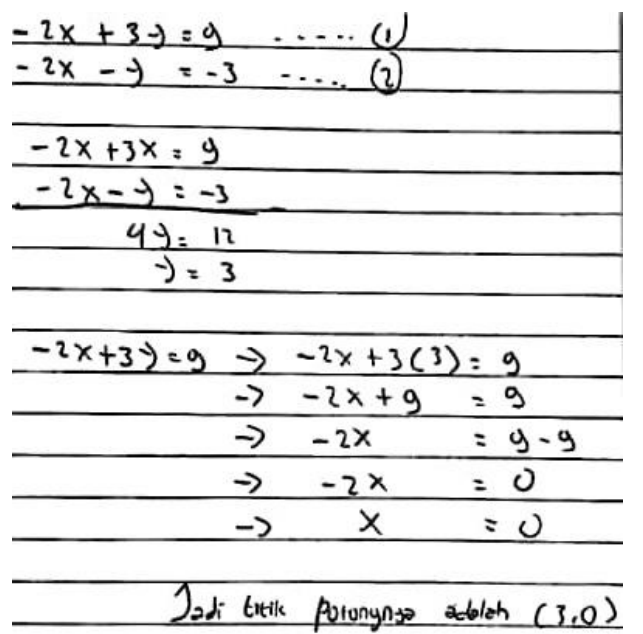

(a)

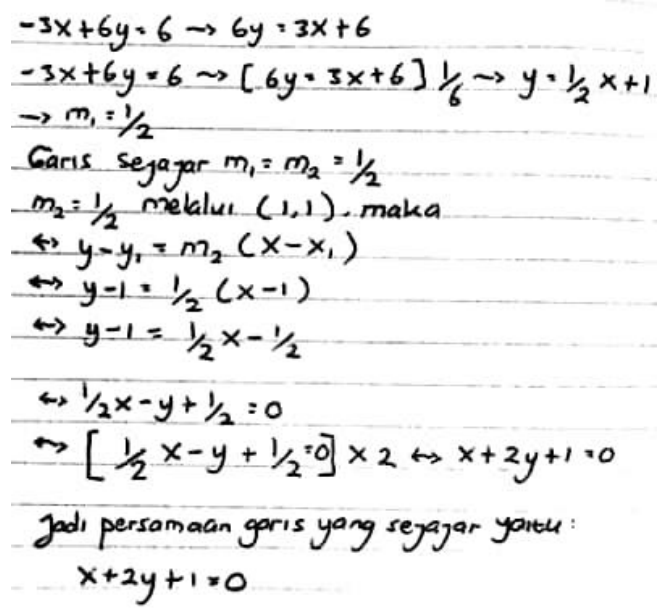

(b)

Figure 9. $(a, b)$ Student Errors in Writing Answers 
DOI: https://doi.org/10.24127/ajpm.v10i4.4221

According to Sukoriyanto (2020), encoding errors is unfortunate because the student has successfully reached the data processing stage but failed to write the final solution. This error occurs due to frustration and lack of understanding of the issues concerned. It's mean that distance learning make understanding obstacle can not be clarify directly and less of stakeout, while direct learning offer real-time supervision also easy to control who are not understand, yet. So, the teacher will feel easy to help without any request before.

The findings in this study suggest that all types of errors can be detected. This indicates that students experience obstacles in learning. Learning and research are carried out while in pandemic conditions, so face-to-face learning cannot be implemented. The advantages of this data are very detailed on behaviour, so the discussion is very in-depth. However, it is necessary to be careful in choosing the subject, so that the data is truly accurate.

In its implementation, learning in pandemic times has many obstacles. The obstacles that occur are felt by all parties involved, namely teachers, students and parents. During the study, obesity was conducted to find out the learning obstacles experienced. As a result, it can help make it easier for teachers to understand student learning styles. If it is not implemented, the learning will be disproportionate.

Ownership of mobile phones and unstable networks became the main obstacles in learning during pandemic. Not everystudent have a supportive mobile phone. In addition, parents who have a busy job make supervision of students very lacking. The time that should be used to learn turns into playtime. The availability of decent learning resources cannot be fulfilled.
Teachers are only able to provide pdf material shared through WhatsApp. The material provided is only in the form of pdf files, so that it does not interest.

Student's learning obstacle could be from internal or external factor. In this case, internal factor come from the student's obstacle during learning. While external factor come from teacher and the material lesson. From the data, we know that understanding level of student variety. In the student's case, it could be caused lack of learning readiness or defined as ontogenic obstacle. Students tend to be careless in doing questions like this. This is happens when students determine the question 1 to 3 . In another case, teachers still can not suspect directly as well. This causes the teacher to be unable to break these ontogenic barriers (Yusuf et al., 2017). In another side, students does not got didactic obstacle that come from knowledge level. It's proven by all the question was answered as well, even there was view mistakes.

As a part of learning, teacher always provide many materials for students. But students still confuse with the question, even it is low level question. In this case, point of view come to the the availability of decent learning resources cannot be fulfilled. Teachers provide .pdf material shared through WhatsApp and explain it once by online cloud meeting. Communication method during distance learning should be rich and variety (Wakefield \& Frawley, 2020). The general method is currently not interesting again, or students feel bored by the media. So, they are too lazy to open the file, even the answer is available. This condition become one of student's difficulties. So, the availability of decent learning need to be pointed as well. 
According to the analysis, it is important to pay attention to student barriers, to provide appropriate solutions in the future. This research will be a fresh finding for researchers, to help practitioners in schools overcome student learning barriers. Thus, learning will be better and more complete.

\section{CONCLUSION AND SUGGESTION}

Overall, it can be seen that all the subjects of the study made mistakes on the given problem, although not all the problems they did were wrong. Mistakes made between one study subject and another are almost always the same. Detection of student's barriers by using NEA is work properly as well. It could be conclude that every student has varieties obstacles as learning barriers. Student errors that appear to indicate obstacles in learning. The number of mobile phones and unstable internet networks, minimal learning supervision, and the availability of learning resources are lacking. Need an innovation to break this learning barrier. The results of this study could be used as a basis reference for developing a future solution in order to built better education in the future.

From this study it could be suggest that need for deep analysis on student's barrier through PPKM, not only by using NEA theory. It also need of teacher awareness about everything student's barriers, before they teach a topic. It is important to enhance education.

\section{REFERENCES}

Ahmadi, R. (2021). Students' perceptions of student voice in assessment within the context of Iran: the dynamics of culture, power relations, and student knowledge. Higher Education

Research and Development, O(0), $1-15$.

https://doi.org/10.1080/07294360. 2021.1882401

Anugrah, T. M., \& Kusmayadi, T. A. (2019). An Error Analysis: Problem Solving of The Maximum and Minimum Derivative Values With Newman's Error Analysis. Journal of Mathematics and Mathematics Education, 9(1), 44. https://doi.org/10.20961/jmme.v9i 1.48288

Ferdianto, F., \& Hartinah, S. (2020). Analysis of the Difficulty of Students on Visualization Ability Mathematics Based on Learning Obstacles. 429(Icasseth 2019), 227-231.

https://doi.org/10.2991/assehr.k.2 00402.053

Fitriana, L., Hendriyanto, A., Sahara, S., \& Akbar, F. N. (2021). Digital Literacy: The Need for Technology-Based Learning Media in the Revolutionary Era 4.0 for Elementary School Children. International Journal of Progressive Sciences and Technologies (IJPSAT), 26(1), 194-200.

Hamukwaya, S. T., \& Haser, Ç. (2021). "It does not Mean that They Cannot Do Mathematics": Beliefs about Mathematics Learning Difficulties. International Electronic Journal of Mathematics Education, 16(1), em0622. https://doi.org/10.29333/iejme/95 69

Hanifah, N. F., Hidayat, W., \& Aripin, U. (2020). Gender Perspective and Newman'S Theory in Error Analysis of Students' Answers in 
DOI: https://doi.org/10.24127/ajpm.v10i4.4221

Ratio and Proportion. Kalamatika: Jurnal Pendidikan Matematika, 5(2), 103-118. https://doi.org/10.22236/kalamati ka.vol5no2.2020pp103-118

Hendriyanto, A., Kusmayadi, T. A., \& Fitriana, L. (2021a). Explain Point and Line Positioning Materials Using the Ethnomathematical Approach to Enhance Students' Geometric Thinking Skills. Psychology and Education, 58(5), 4199-4214.

Hendriyanto, A., Kusmayadi, T. A., \& Fitriana, L. (2021b). What are the type of learning media innovation needed to support distance learning? AKSIOMA: Jurnal Program Studi Pendidikan Matematika, 10(2), 1043-1052.

Hill, C., Rosehart, P., St. Helene, J., \& Sadhra, S. (2020). What kind of educator does the world need today? Reimagining teacher education in post-pandemic Canada. Journal of Education for Teaching, 46(4), 565-575. https://doi.org/10.1080/02607476. 2020.1797439

Isnani, Waluya, S. B., Rochmad, \& Wardono. (2020). Analysis of mathematical creativity in mathematics learning is open ended. Journal of Physics: Conference Series, 1511(1). https://doi.org/10.1088/17426596/1511/1/012102

Murtiyasa, B., \& Wulandari, V. (2020). Analisis Kesalahan Siswa Materi Bilangan Pecahan Berdasarkan Teori Newman. AKSIOMA: Jurnal Program Studi Pendidikan Matematika, 9(3), 713. https://doi.org/10.24127/ajpm.v9i 3.2795

Siskawati, E., Zaenuri, \& Wardono. (2021). Analysis of students' error in solving math problem-solving problem based on Newman Error Analysis (NEA). Journal of Physics: Conference Series, 1918(4).

https://doi.org/10.1088/17426596/1918/4/042108

Son, A. L., Darhim, \& Fatimah, S. (2020). Students' Mathematical Problem-Solving Ability Based. Journal on Mathematics Education, 11(2), 209-222.

Sukardi, R. R., Sopandi, W., \& Riandi. (2021). How do teachers develop secondary school students' creativity in the classroom? AIP Conference Proceedings, 2331(April). https://doi.org/10.1063/5.0042030

Sukoriyanto. (2020). Students' errors analysis in solving the geometry word problem based on Newman stage. AIP Conference Proceedings, 2215(April). https://doi.org/10.1063/5.0000490

Trapsilasiwi, D., Murtikusuma, R. P., Hobri, Oktavianingtyas, E., Wiliandani, I., \& Widodo, D. M. (2021). Analysis of Introverted Students' Error Based on Newman in Solving Arithmetic Sequences and Series Problems. Proceedings of the $1 s t$ International Conference on Mathematics and Mathematics Education (ICMMEd 2020), 550(Icmmed 2020), 371-375. https://doi.org/10.2991/assehr.k.2 10508.090

Wakefield, J., \& Frawley, J. K. (2020). How does students' general academic achievement moderate the implications of social networking on specific levels of learning performance? Computers and Education, 144(June 2019). https://doi.org/10.1016/j.compedu 
DOI: https://doi.org/10.24127/ajpm.v10i4.4221

.2019 .103694

Wijaya, T. T., Ying, Z., Purnama, A., \& Hermita, N. (2020). Indonesian students' learning attitude towards online learning during the coronavirus pandemic. Psychology, Evaluation, and Technology in Educational Research, 3(1), 17-25. https://doi.org/10.33292/petier.v3i 1.56

Yusuf, Y., Titat, N., \& Yuliawati, T. (2017). Analisis Hambatan Belajar (Learning Obstacle) Siswa SMP Pada Materi Statistika. Aksioma, $8(1), \quad 76$. https://doi.org/10.26877/aks.v8i1. 1509 